\title{
THE INFLUENCE OF ORALLY ADMINISTERED ALKALI AND ACID ON THE RENAL EXCRETION OF QUINACRINE, CHLOROQUINE AND SANTOQUINE ${ }^{1}$
}

\author{
By JOSEPH W. JAILER, MORRIS ROSENFELD, AND JAMES A. SHANNON \\ (From the Research Service, Third Medical Division, Goldwater Memorial Hospital, and the \\ Department of Medicine, New York University)
}

(Received for publication July 17, 1947)

Haag and Larson (1) demonstrated in 1942 that in the case of nicotine the extent of urinary excretion of a chemical may be related to the reaction of urine. They emphasized the importance of taking into consideration the dissociation constant of a drug and the relative reabsorbability of the free and dissociated base. Extending these studies to the urinary excretion of quinine in man, Haag, Larson and Schwartz (2) found in 1943 that the urinary output could be doubled by passing from an alkaline to an acid urine and they ascribed the difference to greater resorption of quinine from the urinary tract when the urine is alkaline.

In connection with studying the behavior of newer antimalarial drugs in man, the extent of the influence of urinary acid-base balance upon renal excretion was re-examined. Parallel studies by Emerson and Dole (3) indicated that renal clearance of quinacrine is subject to 100 -fold variations due principally to 2 variables, the urinary $\mathrm{pH}$ and the renal plasma flow. Work conducted at the same time by the Army Malaria Research Unit at Oxford (4) emphasized the striking parallelism between urinary excretion of quinacrine and ammonia. They found that the ratio of urinary quinacrine to urinary ammonia is directly proportional to the plasma quinacrine concentration. Trager and Hutchinson (5) in 1946 similarly found the urinary excretion of quinacrine to be closely correlated with the urinary excretion of ammonia.

The present investigation was designed to ascertain the effect of oral ingestion of alkali and acid upon the renal excretion of this general type of organic compound. The substances selected

\footnotetext{
1 This work was carried out under a contract recommended by the Committee on Medical Research between the Office of Scientific Research and Development and New York University.
}

for study were quinacrine, chloroquine ( $\mathrm{SN}$ 7618), and santoquine ( $\mathrm{SN}-6911)$.

\section{METHODS AND MATERIALS}

The patients utilized in this study were from the middle and older age groups. No restriction was placed on the diet or upon water intake during the observations and the patients were permitted the freedom of the ward. All drugs were administered orally and according to a single general dosage pattern. A high initial dose was administered during the first 24 hours and this was followed by the serial administration of smaller maintenance doses. Several days were allowed to elapse for the stabilization of the plasma drug concentration before observations were begun.

Alkali was administered orally in the form of sodium bicarbonate at a total daily dose of 20 grams. This was given in doses of 2.5 grams at 2-hour intervals during the day for 7 doses and once during the night. Acid was administered orally in the form of ammonium chloride at a total daily dose of 8 grams. The dosage schedule was the same as for the bicarbonate, each dose being 1.0 gram.

Plasma and urine estimations were performed by methods developed by Brodie. Quinacrine was determined fluorometrically by the single extraction procedure using ethylene dichloride (6); the alkaline wash was used in the urine determinations but not in the plasma determinations. The ethylene dichloride extract was made acid with trichloracetic acid (Masen [7]). Santoquine was estimated by the colorimetric procedure depending upon a salt formation with methyl orange (Brodie et al [8]).

The recently developed specific method (1947) for the analysis of chloroquine (9), involving the use of heptane and alkaline washes, was not yet available at the time of the present study. The procedure used involved the extraction of chloroquine with ethylene dichloride at $\mathrm{pH} 11$, followed by the return of the drug to dilute acid. The acid solution was buffered at $\mathrm{pH}$ 9.5 and subjected to ultra-violet irradiation for a 1-hour period. Concentration was estimated by measurement of fluorescence generated by the irradiation. This procedure includes in the measurement interfering degradation products of chloroquine which are found in plasma to the extent of 20 to 50 per cent. However, it is quite specific for urine since only negligible amounts of these degradation products appear in urine. 
Urine $\mathrm{pH}$ was determined in all cases on freshly voided urine samples using a glass electrode. No precautions were taken to maintain $\mathrm{CO}_{2}$ tensions in the transfer of fluid. Consequently the data on urinary $\mathrm{pH}$ must be taken as close approximations rather than precise estimations of the $\mathrm{pH}$ of bladder urine. During the period of alkali administration the urinary $\mathrm{pH}$ rose to values between 7.5 and 8.0 ; during the acid period the $\mathrm{pH}$ fell to values of 4.0 to 5.0 .

\section{RESULTS}

\section{Quinacrine}

The experimental data obtained on 4 patients receiving maintenance doses of 0.2 and 0.3 grams of quinacrine dihydrochloride are summarized in Table I. The amounts and concentrations noted are expressed in terms of free base. The control values for the renal excretion of quinacrine varied from 1 to 3 per cent of the daily dose. Excretion was reduced to 0.07 to 0.3 per cent of the daily dose during alkalinization and increased to 2 to 6 per cent during acidification. There was in individual cases a 14 - to 25 -fold increase in going from one state to the other. As is to be expected, such a change is not reflected in the plasma quinacrine concentration since the extent of renal excretion in relation to the oral dose is low in all cases. The plasma level of quinacrine remained roughly constant in 1 patient who was at equilibrium before the observations were begun, and
TABLE II

The influence of orally administered alkali and acid on the renal excretion of chloroquine $(S N-7618)$

\begin{tabular}{|c|c|c|c|c|c|}
\hline Patient & Si. & Wo. & Ke. & Al. & Ch. \\
\hline \multirow[t]{2}{*}{ Drug intake } & $\underset{\text { per day }}{200}$ & $\begin{array}{c}400 \\
\text { mgm. } \\
\text { per day }\end{array}$ & $\underset{\substack{400 \\
\text { per day }}}{\text { per }}$ & $\begin{array}{c}400 \\
\text { mgmm. } \\
\text { per day }\end{array}$ & $\begin{array}{c}400 \\
\text { per day }\end{array}$ \\
\hline & $\begin{array}{c}\text { Urinary } \\
\text { excre- } \\
\text { tion }\end{array}$ & $\begin{array}{l}\text { Urinary } \\
\text { excre- } \\
\text { tion }\end{array}$ & $\begin{array}{l}\text { Urinary } \\
\text { excre- } \\
\text { tion }\end{array}$ & $\begin{array}{l}\text { Urinary } \\
\text { excre- } \\
\text { tion }\end{array}$ & $\begin{array}{l}\text { Urinary } \\
\text { excre- } \\
\text { tion }\end{array}$ \\
\hline Control period & $\begin{array}{r}113 \\
104 \\
75\end{array}$ & $\begin{array}{c}\text { milligr } \\
30 \\
105 \\
99\end{array}$ & $\begin{array}{c}\text { ams per } \\
133 \\
84 \\
119\end{array}$ & $\begin{array}{r}4 \text { hours } \\
62 \\
110 \\
103\end{array}$ & $\begin{array}{r}110 \\
60\end{array}$ \\
\hline $\begin{array}{l}\mathrm{NaHCO}_{3} \\
20 \text { grams daily } \\
\text { for } 3 \text { days }\end{array}$ & $\begin{array}{l}47 \\
24 \\
41\end{array}$ & $\begin{array}{l}55 \\
26 \\
17\end{array}$ & $\begin{array}{l}53 \\
34 \\
37\end{array}$ & $\begin{array}{r}136 \\
79 \\
61\end{array}$ & $\begin{array}{l}60 \\
27 \\
30\end{array}$ \\
\hline $\begin{array}{l}\mathrm{NH}_{4} \mathrm{Cl} \\
8.0 \text { grams daily } \\
\text { for } 3 \text { days }\end{array}$ & $\begin{array}{l}119 \\
188 \\
137\end{array}$ & $\begin{array}{r}54 \\
75 \\
114\end{array}$ & $\begin{array}{l}119 \\
208 \\
205\end{array}$ & $\begin{array}{l}147 \\
192 \\
317\end{array}$ & $\begin{array}{r}103 \\
80\end{array}$ \\
\hline
\end{tabular}

increased as a more or less linear function of time in the 2 who had not as yet achieved an equilibrium plasma quinacrine concentration.

\section{Chloroquine}

The experimental data obtained on 5 patients receiving 0.2 or 0.4 grams of chloroquine daily are summarized in Table II. The daily excretion, in terms of percentage of the daily dose, was high in all patients as compared to quinacrine. This varied in the case of chloroquine, from 15 to 50

TABLE I

The influence of orally administered alkali and acid on the renal excretion of quinacrine

\begin{tabular}{|c|c|c|c|c|c|c|c|c|}
\hline Patient & \multicolumn{2}{|c|}{ Wr. } & \multicolumn{2}{|c|}{ Wo. } & \multicolumn{2}{|c|}{$\mathrm{Ni}$. } & \multicolumn{2}{|c|}{ Na. } \\
\hline \multirow[t]{2}{*}{ Drug intake } & \multicolumn{2}{|c|}{300 mgm. per day } & \multicolumn{2}{|c|}{$200 \mathrm{mgm}$. per day } & \multicolumn{2}{|c|}{$200 \mathrm{mgm}$. per day } & \multicolumn{2}{|c|}{200 mgm. per day } \\
\hline & $\begin{array}{c}\text { Urinary } \\
\text { excretion }\end{array}$ & $\underset{\text { level }}{\text { Plasma }}$ & $\begin{array}{l}\text { Urinary } \\
\text { excretion }\end{array}$ & $\begin{array}{c}\text { Plasma } \\
\text { level }\end{array}$ & $\begin{array}{l}\text { Urinary } \\
\text { excretion }\end{array}$ & $\underset{\text { level }}{\text { Plasma }}$ & $\begin{array}{c}\text { Urinary } \\
\text { excretion }\end{array}$ & $\begin{array}{c}\text { Plasma } \\
\text { level }\end{array}$ \\
\hline Control period & $\begin{array}{c}\text { mgm. per } \\
24 \text { hrs. } \\
2.92 \\
7.47 \\
5.98\end{array}$ & $\begin{array}{c}\mu g . \text { per } L \text {. } \\
81\end{array}$ & $\begin{array}{c}\text { mgm. per } \\
24 \text { hrs. } \\
\\
4.63 \\
3.7\end{array}$ & $\begin{array}{c}\mu g . \operatorname{per} L . \\
54\end{array}$ & $\begin{array}{c}\underset{24}{m g m .} \text { her } \\
\\
1.93 \\
0.80\end{array}$ & $\begin{array}{c}\mu g . \text { per } L \text {. } \\
23 \\
31\end{array}$ & $\begin{array}{c}\text { mgm. per } \\
24 \text { hrs. } \\
\\
7.14 \\
4.38 \\
9.3\end{array}$ & $\begin{array}{c}\mu g . \text { per } L . \\
50 \\
54\end{array}$ \\
\hline $\begin{array}{l}\mathrm{NaHCO}_{3} \\
20 \text { grams daily for } 3 \text { days }\end{array}$ & $\begin{array}{l}1.32 \\
0.9 \\
0.98\end{array}$ & & $\begin{array}{l}1.73 \\
0.66 \\
0.54\end{array}$ & $\begin{array}{l}40 \\
59\end{array}$ & $\begin{array}{l}0.33 \\
0.27 \\
0.13\end{array}$ & $\begin{array}{l}48 \\
55\end{array}$ & $\begin{array}{l}2.1 \\
0.79 \\
0.42\end{array}$ & $\begin{array}{l}87 \\
97\end{array}$ \\
\hline $\begin{array}{l}\mathrm{NH}_{4} \mathrm{Cl} \\
8.0 \text { grams daily for } 3 \text { days }\end{array}$ & $\begin{array}{l}5.85 \\
13.6 \\
13.9\end{array}$ & & $\begin{array}{l}6.65 \\
8.25\end{array}$ & 48 & $\begin{array}{l}0.14 \\
1.8 \\
3.2\end{array}$ & 67 & $\begin{array}{r}5.4 \\
10.3 \\
12.1\end{array}$ & 102 \\
\hline
\end{tabular}


per cent in the control periods; was reduced to 7 to 20 per cent during alkalinization and was increased to 20 to 90 per cent during acidification.

\section{Santoquine}

Observations on santoquine were limited to a single individual. However, they were designed to stress the effects of changes in the renal excretion of drug upon the maintenance of the plasma santoquine concentration while on a constant drug intake. Each phase of alkali and acid administration was of 5 days' duration and 2 complete cycles of alkali-acid treatment were obtained (Table III).

TABLE III

The influence of orally administered alkali and acid on the renal excretion of santoquine $(S N-6911)$ Patient McK.

Drug intake: $400 \mathrm{mgm}$. per day

\begin{tabular}{|c|c|c|}
\hline & $\begin{array}{c}\text { Urinary } \\
\text { excretion }\end{array}$ & $\begin{array}{c}\text { Plasma } \\
\text { concentration }\end{array}$ \\
\hline Control period & $\begin{array}{c}\text { mgm. per } \\
24 \text { hrs. } \\
154 \\
107 \\
202 \\
190\end{array}$ & $\begin{array}{c}\begin{array}{c}\text { micrograms } \\
\text { per liter }\end{array} \\
410 \\
400\end{array}$ \\
\hline $\begin{array}{l}\mathrm{NaHCO}_{3} \\
12.0 \text { grams daily } \\
\text { for } 5 \text { days }\end{array}$ & $\begin{array}{l}36 \\
77 \\
56 \\
82\end{array}$ & 630 \\
\hline $\begin{array}{l}\mathrm{NH}_{4} \mathrm{Cl} \\
6.0 \text { grams daily } \\
\text { for } 5 \text { days }\end{array}$ & $\begin{array}{r}90 \\
384 \\
290 \\
249 \\
266\end{array}$ & $\begin{array}{l}738 \\
685 \\
418\end{array}$ \\
\hline $\begin{array}{l}\mathrm{NaHCO}_{3} \\
20.0 \text { grams daily } \\
\text { for } 5 \text { days }\end{array}$ & $\begin{array}{r}199 \\
49 \\
37 \\
60 \\
40\end{array}$ & $\begin{array}{r}432 \\
775 \\
1010\end{array}$ \\
\hline $\begin{array}{l}\mathrm{NH}_{4} \mathrm{Cl} \\
8.0 \text { grams daily } \\
\text { for } 5 \text { days }\end{array}$ & $\begin{array}{l}166 \\
181 \\
191 \\
149 \\
183\end{array}$ & $\begin{array}{l}881 \\
343 \\
324\end{array}$ \\
\hline
\end{tabular}

It should be noted that a large portion of the daily dose of santoquine is excreted in the urine. This was perhaps more in the patient utilized than is usual. During the control period average renal excretion accounted for 41 per cent of the daily dose. This was decreased to an average of 16 per cent during the first alkalinization and increased to an average of 64 per cent during the first acidification. Similar results were obtained during the second cycle.

As is to be expected in such a circumstance, the plasma santoquine concentrations reveal a cycle which can be correlated with the intervals of low and high renal excretion. During the alkaline phase of low drug excretion, the plasma level slowly rose; during the acid phase of high excretion, the plasma level fell.

\section{DISCUSSION}

It is apparent from the data that the renal excretion of the anti-malarial drugs is dependent upon a series of variables in addition to the concurrent plasma concentration. These variables are of sufficient importance in the determination of the renal drug excretion, that the latter may not be used directly as an approximation method to estimate the general level of the plasma drug concentration.

The refinement introduced by the British workers (4) involving the simultaneous measurement of urinary ammonia and quinacrine does permit of an indirect determination of plasma quinacrine from measurements on urine alone. It appears to us that ammonia excretion may be governed by urinary acid-base balance in a manner similar to the other weak organic bases, such as the anti-malarial drugs. The ammonia measurement provides an index of variation in urinary acid-base balance. By taking the quinacrine concentrations in relationship to ammonia excretion, the Oxford workers were able to eliminate the variable of $\mathrm{pH}$. Trager and Hutchinson (5) seem to ascribe a causal role to ammonia in promotion of urinary excretion; it appears far more likely that ammonia and quinacrine excretions are concomitantly altered in a similar manner by urinary changes in hydrogen ion concentration.

The experimental data are interesting for yet another reason. It must be assumed that at least a portion of the drug eliminated by the kidneys is excreted by a process other than glomerular filtration. This follows from a consideration (in the case of quinacrine) of the extent to which it is bound to the non-diffusible constituents of plasma (some 80 to 90 per cent of the total) and the observed rates of excretion. The mechanism responsible for such tubular excretion as occurs ap- 
pears to be quite different from those responsible for the tubular excretion of such substances as phenol red, creatinine, diodrast, etc. The latter manifest considerable stability whereas this does not obtain for the tubular excretion either of quinacrine or of chloroquine and santoquine.

Data are not available with which to define the mechanisms involved though there is sufficient to warrant certain reasonable speculations. It is suggested that a small portion of the excreted anti-malarial drug is filtered at the glomerulus, the amount determined by the glomerular filtration rate, and the concentration of unbound drug in plasma water. A second portion is considered to be added to this in the proximal segment by a process of active tubular excretion similar to the conventional processes considered above. The combined filtered and secreted drug is presented to the distal segment of the nephron in concentrated form due in part to the reabsorption of water in the proximal tubule and loop of Henle. In the distal segment, a process of adjustment of hydrogen ion concentration takes place followed by equilibration of drug across the tubular membrane. The data are in keeping with the assumption that free base is more freely diffusible across the cells of the distal segment than the monoacidic and diacidic salts of the drugs studied. Such being the case there may be expected to be net gain or loss of drug depending upon the relation between the hydrogen ion concentration of the tubular urine and that of peritubular fluid (ca. 7. 34). Alkalinization of the tubular urine would increase the proportion of drug in the form of free base and in this way would promote reabsorption; acidification would counteract reabsorption by reducing the proportion of free base. A somewhat similar mechanism has been suggested to cover the renal tubular excretion of neutral red in the amphibian kidney (10).

The observation of Trager and Hutchinson (5) that the plasma quinacrine level rose soon after oral ingestion of large doses of ammonium chloride, would seem to provide another basis for the altered urinary excretion. The elevation in plasma level observed in their experiment is of brief duration and is in keeping with the increased plasma levels observed in dog experiments (11) in which acute acidosis was produced by $\mathrm{CO}_{2}$ administra- tion. The plasma quinacrine measurement in the present study revealed no significant changes in level since by design the blood sampling and ammonium chloride administration were timed to elicit only sustained changes. The promotion of urinary excretion of quinacrine by ammonium chloride appears to us not to be secondary to plasma drug elevation but rather a direct result of the acid urine counteracting drug reabsorption in the tubules.

Relatively large changes in excretion rate are expected to be reflected in changes in the plasma drug level on a constant regimen of oral dosage only when the absolute rate of excretion of the substance is high. This phenomenon is brought out strikingly in the patient receiving santoquine. During the acid periods drug excretion amounted to as much as 50 to 75 per cent of the orally administered dosage. The effective dosage was thereby reduced to $1 / 2$ or $1 / 4$ of the actual administered dose. During the alkaline period, the per cent of drug excretion was small, namely 20 per cent of the ingested dose. Under these circumstances, the effective oral dose was as high as 80 per cent of the actual administered dosage.

Quinacrine excretion, though markedly altered by acid-base changes, remains in all circumstances such a small percentage of the orally administered dosage that changes in renal elimination would not be reflected in the maintained plasma level. The changes in drug excretion, from 0.2 per cent during the alkaline period to 4 per cent in the acid period, would not reduce the effective oral dosage to an appreciable extent. The actual measurements on quinacrine plasma levels in the present experiment showed no cyclic fluctuation in acid and alkaline phases as were observed with santoquine.

One therapeutic implication of the above results is obvious. When toxicity is encountered during the administration of certain anti-malarial drugs, ácidification of the urine by ammonium chloride would promote renal excretion of the drug. Effectiveness of such therapy should be good only with drugs of high excretion rate such as chloroquine and santoquine. With a drug like quinacrine which is excreted in the urine to only a slight degree even upon acidification, such therapy should have little value. 


\section{SUMMARY}

1. The oral administration of ammonium chloride increases the renal excretion of quinacrine, chloroquine and santoquine in individuals on a constant maintenance dose of the drugs. Sodium bicarbonate given in a similar manner causes a retention of these drugs.

2. Changes in renal excretion are reflected in changes in plasma level only when the absolute rate of excretion of the substance is high.

\section{BIBLIOGRAPHY}

1. Haag, H. B., and Larson, P. S., Studies on the fate of nicotine in the body; the effect of $\mathrm{pH}$ on the urinary excretion of nicotine by tobacco smokers. J. Pharmacol. \& Exper. Therap., 1942, 76, 235.

2. Haag, H. B., Larson, P. S., and Schwartz, J. J., The effect of urinary $\mathrm{pH}$ on the elimination of quinine in man. J. Pharmacol. and Exper. Therap., 1943, 79, 136.

3. Emerson, K., and Dole, V. P., The renal excretion of atabrine. Malaria Report No. 246, Board for the coordination of malaria studies, 1943.
4. Army Malaria Research Unit. Factors affecting the excretion of mepacrine in the urine. Ann. Trop. Med., 1945, 39, 53.

5. Trager, W., and Hutchinson, M. C., The influence of ammonium ion on the plasma atabrine level and on the urinary excretion of atabrine. J. Clin. Invest., 1946, 25, 694.

6. Brodie, B. B., and Udenfriend, S., The estimation of atabrine in biological fluids and tissues. J. Biol. Chem., 1943, 151, 299.

7. Masen, J. Personal communication.

8. Brodie, B. B., Udenfriend, S., and Dill, W., The estimation of basic organic compounds in biological material; estimation by salt formation with methyl orange. J. Biol. Chem., 1947, 168, 335.

9. Brodie, B. B., Udenfriend, S., Dill, W., and Chenkin, T., The estimation of basic organic compounds in biological material; estimation by conversion to fluorescent compounds. J. Biol. Chem., 1947, 168, 319.

10. Kempton, R. T., Differences in the elimination of neutral red and phenol red by the frog kidney. J. Cell. and Comp. Physiol., 1939, 14, 73.

11. Jailer, J. W., Rosenfeld, M., Zubrod, G., and Shannon, J. A. In press. 